Ziadir Francisco Coutinho ${ }^{1}$

\title{
Paracoccidioidomycosis mortality in Brazil (1980-1995)
}

\author{
Mortalidade por paracoccidioidomicose \\ no Brasil (1980-1995)
}

Delson da Silva ${ }^{2}$

Márcia Lazéra ${ }^{3}$

Valéria Petri 4

Rosely Magalhães de Oliveira 2

Paulo C. Sabroza 2

Bodo Wanke 3

1 Centro de Saúde Escola Germano Sinval Faria, Escola Nacional de Saúde Pública, Fundação Oswaldo Cruz. Rua Leopoldo Bulhões 1480, Rio de Janeiro, $R J$ 21041-210, Brasil. ziadir@centroin.com.br 2 Departamento de Endemias Samuel Pessoa, Escola Nacional de Saúde Pública, Fundação Oswaldo Cruz. Rua Leopoldo Bulhões 1480, Rio de Janeiro, $R J$ 21041-210, Brasil. delson@ensp.fiocruz.br rosely@ensp.fiocruz.br sabroza@ensp.fiocruz.br 3 Serviço de Micologia, Centro de Pesquisa Hospital Evandro Chagas,

Fundação Oswaldo Cruz. Av. Brasil 4365,

Rio de Janeiro, $R J$ 21045-900, Brasil. lazera@cpqhec.fiocruz.br wanke@cpqhec.fiocruz.br ${ }^{4}$ Departamento de Dermatologia, Escola Paulista de Medicina, Universidade Federal de São Paulo. Rua Pedro de Toledo 928, São Paulo, SP 04039-020, Brasil. valeriapetri@uol.com.br
Abstract This study analyzes 3,181 deaths from paracoccidioidomycosis in Brazil, based on 16 years of sequential data (from 1980 to 1995). During this period paracoccidioidomycosis showed considerable magnitude and low visibility, representing the eighth most common cause of death from predominantly chronic or recurrent types of infectious and parasitic diseases. It also had the highest mortality rate among the systemic mycoses. The mean annual mortality rate was 1.45 per million inhabitants, indicating a downward long-term trend (reduction of 31.28\%), while spatial distribution among the different regions and States of Brazil was non-homogenous. The South (with the highest regional rate) and the Southeast showed a downward trend, while the Central West had the second highest rate in the country. At least one-fifth of Brazilian municipalities (or $22.71 \%$ of the country's total area) reported deaths from paracoccidioidomycosis. Overall nationwide mortality per area was $3.73 / 10,000 \mathrm{~km}^{2}$. The disease was endemic in non-metropolitan areas. The majority of deaths occurred in males (84.75\%), and there was a sex ratio of 562 men/100 women. The 30-59-year and over-60-year age groups were the most affected. The study showed that the mortality rate justifies classifying this disease as a major health problem in Brazil.

Key words Paracoccidioidomycosis; Mortality; Epidemiology; Endemic Mycosis

Resumo Foram estudados 3.181 óbitos por paracoccidioidomicose no Brasil, a partir de séries temporais de 16 anos (1980-1995). No período, esta micose mostrou grande magnitude e baixa visibilidade, destacando-se como oitava causa de mortalidade por doença predominantemente crônica ou repetitiva, entre as infecciosas e parasitárias, e a mais elevada taxa de mortalidade entre as micoses sistêmicas. A taxa de mortalidade média anual foi de 1,45/milhão de habitantes, com tendência secular em queda (redução de 31,28\%), a distribuição espacial não foi homogênea entre as diferentes regiões e Estados. O Sul, com a maior taxa regional, e o Sudeste apresentaram tendência a queda. A Região Centro-Oeste teve o segundo coeficiente mais alto do País, com tendência a ascensão. Houve registro de óbitos pela endemia em cerca de um quarto dos municípios brasileiros, estendendo-se por 22,71\% de sua área. A densidade geral de óbitos foi de 3,73 óbitos $/ 10.000 \mathrm{~km}^{2}$. A doença prevaleceu como endemia nas áreas não metropolitanas. A taxa de mortalidade predominou em indivíduos do sexo masculino, com 84,75\% dos óbitos e razão de masculinidade de 562 homens/100 mulheres. O grupo etário entre 30-59 anos foi o mais atingido, seguido dos indivíduos com 60 anos ou mais. $O$ estudo mostrou que a taxa de mortalidade pode ser considerada como indicador para definir a doença como importante agravo de saúde no Brasil.

Palavras-chave Paracoccidioidomicose; Mortalidade; Epidemiologia; Micose Endêmica 


\section{Introduction}

Paracoccidioidomycosis is the most important systemic mycosis in Brazil, the country with the most endemic areas for this disease in the world. The etiologic agent of this mycosis is the dimorphous fungus Paracoccidioides brasiliensis, and its eco-epidemiological characteristics are the least understood of all the systemic mycoses (Wanke \& Londero, 1994). Reporting the disease is not mandatory in Brazil, and there is no specific control program or standardized diagnostic or treatment protocol.

Autochthonous cases of this endemic disease occur exclusively in regions of Latin America, with a marked prevalence among low-income population strata, particularly those associated with farm labor (Bethlem et al., 1991; Forjaz, 1989; Restrepo, 1985; Silva-Vergara et al., 1998). In areas classified as highly endemic, the annual incidence rate is estimated at three cases per 100 thousand inhabitants (Londero \& Ramos, 1990; Restrepo-Moreno \& Greer, 1983). Tuberculosis is associated with the disease in some $10 \%$ of paracoccidioidomycosis cases (Giménez, 1998), leading to difficulty in diagnosis and treatment (Coimbra Jr. et al., 1994; Wanke, 1998). High treatment drop-out rates (up to $30 \%$ ) have been reported, depending on the treatment regimen (Valle et al., 1993). Case fatality appears to vary considerably (from 2 to $23 \%$ ), and when associated with AIDS it can reach $30 \%$ (Marques, 1998; Marques et al., 1998; Terra, 1993).

Based on intradermal sensitivity surveys with paracoccidioidin in Brazil, Colombia, and Venezuela, the $P$. brasiliensis infection rate is estimated at $10 \%$ of the population in endemic areas (Bethlem et al., 1991; Wanke \& Londero, $1994,1998)$. However, regional variations in infection prevalence have been verified by different epidemiological surveys (Bagatin, 1986; Coimbra Jr. et al., 1994; Fava \& Fava Netto, 1998; Pedrosa, 1976; Wanke, 1976).

This study aims to analyze the paracoccidioidomycosis mortality distribution in Brazil and to identify possible relations between social, biological, and ecological/environmental determinants.

The study is based on mortality data, the only form of data currently available. Given that the health/disease process is complex and dynamic, the discussion focuses on an epiphenomenon, the final stage of this process, representing a snapshot or a static and partial impression of a whole. In addition, morbidity and mortality indicators express the health/disease process quantitatively, without grasping its nonquantifiable aspects. Temporal trends analysis allows one to retrieve some elements from the disease dynamics, but it still fails to address all the questions (Barreto \& Carmo, 1995). Despite these limitations of mortality data, one can discuss the dynamics of their spatial distribution and use them as an important marker for this health problem.

The principal goal is to identify and discuss the issues involved in dying from paracoccidioidomycosis, mapping the spatial distribution of deaths from this disease, describing its characteristics, and analyzing the probable factors associated with the production of these deaths.

\section{Material and methods}

Paracoccidioidomycosis mortality data are presented for the 16-year historical series from 1980 to 1995 . The databases used to determine the mortality rates were the Brazilian Ministry of Health's Mortality Information System, or SIM (MS, 1996) and the Brazilian National Censuses of 1980 and 1991 (IBGE, 1981, 1992). Deaths were coded according to the 9th Edition of the International Classification of Diseases (OMS, 1985) as paracoccidioidomycosis (ICD 116.1) and blastomycosis (ICD 116.0), excluding those referring to Jorge Lobo disease or lobomycosis (ICD 116.2).

Variables selected for the current study were gender, age, occupation, and place of residence. Data were distributed and analyzed according to the following analytical units: country, regions, States, metropolitan areas, and State capitals. Occupations were analyzed according to situation in the labor market, separating the "poorly defined" categories (not in the labor force, students, unemployed, housewives, and unknown occupation) from the others. The latter occupations were aggregated by means of approximation with the national census categories.

Mean mortality rates per million inhabitants for the period from 1980 to 1995 were calculated for selected groups of diseases, excluding sarcoidosis (ICD 135.9/5) and including AIDS (ICD 279.1/0). Paracoccidioidomycosis mortality rates were compared to those of other infectious diseases, focusing on the most important Brazilian endemics and other systemic mycoses accounting for the most deaths. A classification was thus produced according to the normal evolution of predominantly acute as compared to predominantly chronic and/or recurrent diseases.

The SIM does not specify occurrence of the death in terms of the individual's urban or rural residence. In addition to the occupational 
profile, in order to deal with this question, the study focused on the distribution of deaths from blastomycotic infections according to metropolitan regions and from paracoccidioidomycosis in the State capitals. According to the ICD, so-called blastomycotic infections include not only blastomycosis and paracoccidioidomycosis but also lobomycosis. This approach was used because during the period under study in the metropolitan regions, the data available in the Mortality Information System add together the total deaths from these three causes.

The paracoccidioidomycosis mortality density per 10 thousand $\mathrm{km}^{2}$ was also calculated according to country, regions, and States. This indicator allowed for an approach to the spatial distribution of deaths, in this case more specifically with regard to the distribution of the etiologic agent in the environment (Kawa, 1998). The objective was thus to display the environmental risk of paracoccidioidomycosis. The mortality density indicator was calculated using two different territorial areas as the denominator. The first refers to mortality density in relation to the total area of the region or State (maintaining the same denominator as the mortality rate) and was called overall mortality density. The second expresses the territorial base only for the municipalities that reported deaths from paracoccidioidomycosis and was called mortality density. This observation used the Ministry of Health database of municipalities subsequent to 1991. For the period from 1980 to 1995, the population mortality density was also calculated as the ratio between the number of paracoccidioidomycosis deaths and the population density in inhabitants / 10 thousand $\mathrm{km}^{2}$, so as to provide a direct relationship with the distribution of deaths by area. Other indicators included: (1) proportion of deaths in the regions and States as compared to deaths in the country as a whole; (2) mortality dispersion by municipalities in each territorial unit analyzed, expressed as the percentage of municipalities that recorded deaths in relation to the total municipalities in the unit analyzed; (3) proportion of area affected, obtained from the sum total of the municipal areas affected in relation to the total for the unit analyzed; and (4) the concentration or polarity of deaths in the State capitals.

\section{Results and discussion}

The mean annual mortality rate for paracoccidioidomycosis in Brazil for the period from
1980 to 1995 was 1.45 per million inhabitants (Table 1). The disease accounted for 3,181 deaths in the country, with an annual mean of 198.81 deaths. The deaths displayed a spatial distribution with great territorial dispersion (Figure 1). An overall downward trend of $31.28 \%$ was observed in the mortality rates during the period analyzed (Figure 2).

Table 1

Deaths and mortality rates from paracoccidioidomycosis by States and regions. Brazil, 1980 to 1995 .

\begin{tabular}{|c|c|c|c|c|}
\hline States & $\begin{array}{l}\text { Total } \\
\text { deaths }\end{array}$ & $\begin{array}{l}\text { Mean } \\
\text { deaths/year }\end{array}$ & $\begin{array}{l}\text { Mean } \\
\text { population }\end{array}$ & $\begin{array}{l}\text { Annual } \\
\text { mortality rate }\end{array}$ \\
\hline Acre & 18 & 1.13 & 379,887 & 2.96 \\
\hline Amapá & 1 & 0.06 & 254,004 & 0.25 \\
\hline Amazonas & 15 & 0.94 & $1,871,122$ & 0.50 \\
\hline Pará & 50 & 3.13 & $4,405,854$ & 0.71 \\
\hline Rondônia & 51 & 3.19 & 873,824 & 3.65 \\
\hline Roraima & 1 & 0.06 & 161,434 & 0.39 \\
\hline Tocantins & 15 & 0.94 & 921,832 & 1.02 \\
\hline North & 151 & 9.44 & $8,886,258$ & 1.06 \\
\hline Alagoas & 10 & 0.63 & $2,322,505$ & 0.27 \\
\hline Bahia & 59 & 3.69 & $11,015,421$ & 0.33 \\
\hline Ceará & 5 & 0.31 & $6,005,541$ & 0.05 \\
\hline Maranhão & 22 & 1.38 & $4,605,013$ & 0.30 \\
\hline Paraíba & 2 & 0.13 & $3,049,019$ & 0.04 \\
\hline Pernambuco & 12 & 0.75 & $6,784,063$ & 0.11 \\
\hline Piauí & 14 & 0.88 & $2,422,591$ & 0.36 \\
\hline Rio Grande do Norte & 4 & 0.25 & $2,232,413$ & 0.11 \\
\hline Sergipe & 2 & 0.13 & $1,370,943$ & 0.09 \\
\hline Northeast & 130 & 8.13 & $39,810,495$ & 0.20 \\
\hline Espírito Santo & 107 & 6.69 & $2,400,797$ & 2.79 \\
\hline Minas Gerais & 398 & 24.88 & $14,950,033$ & 1.66 \\
\hline Rio de Janeiro & 252 & 15.75 & $12,302,470$ & 1.28 \\
\hline São Paulo & 950 & 59.38 & $29,358,942$ & 2.02 \\
\hline Southeast & 1,707 & 106.69 & $59,019,248$ & 1.81 \\
\hline Paraná & 462 & 28.88 & $8,205,400$ & 3.52 \\
\hline Rio Grande do Sul & 280 & 17.50 & $8,675,671$ & 2.02 \\
\hline Santa Catarina & 133 & 8.31 & $4,228,772$ & 1.97 \\
\hline South & 875 & 54.69 & $21,112,276$ & 2.59 \\
\hline Federal District & 17 & 1.06 & $1,461,511$ & 0.73 \\
\hline Goiás & 99 & 6.19 & $3,670,868$ & 1.69 \\
\hline Mato Grosso & 87 & 5.44 & $1,690,737$ & 3.22 \\
\hline Mato Grosso do Sul & 115 & 7.19 & $1,638,426$ & 4.39 \\
\hline Central West & 318 & 19.88 & $8,467,380$ & 2.35 \\
\hline Brazil & 3,181 & 198.81 & $137,326,704$ & 1.45 \\
\hline
\end{tabular}

Source: DATASUS/MS and IBGE.

Note: mortality rate per 1,000,000 inhabitants. 


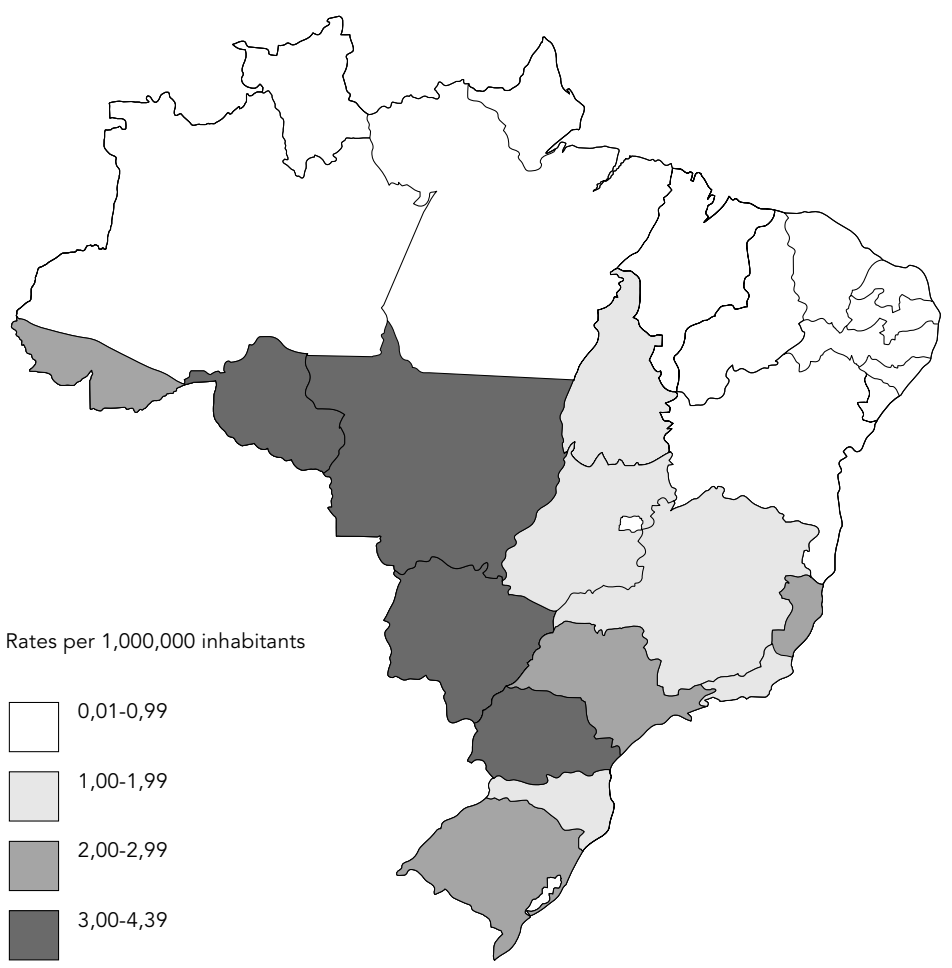

Source: IBGE and DATASUS/MS ioidomycosis and 1,462 (45.96\%) to blastomycosis. Although the term "paracoccidioidomycosis" was recommended and adopted in 1971 (PAHO, 1972), the data still showed nearly half of the deaths recorded under the term "blastomycosis". However, the term blastomycosis is now officially limited to the infection caused by the fungus Blastomyces dermatitidis, a systemic mycosis endemic to North America and several African countries and which has not been reported thus far in Brazil. The cases reported as blastomycosis in Brazil thus refer to the outdated term "South American blastomycosis", now officially replaced by "paracoccidioidomycosis".

As for patients' occupation, 1,587 (49.9\%) had well-defined occupations and were in the labor force, while 1,593 (50.1\%) were not in the formal labor market: 769 (24.2\%) were retired, while information was lacking for 530 (16.7\%). The distribution of well-defined occupations showed that 886 (55.83\%) were agricultural workers, followed by 306 (19.28\%) construction workers. These two occupational categories together accounted for $1,192(75.11 \%)$ of the deaths among patients with specified occupations. Therefore, the majority of individuals in clearly-defined occupational categories worked in the most common jobs among low-income segments of the Brazilian population. Occupational analysis showed that paracoccidioidomycosis is a major occupational disease, principally among rural workers, corroborating previous studies (Bethlem et al., 1991; Negroni, 1993; Restrepo, 1985). Although taking into account the possibility that construction workers may have acquired the $P$. brasiliensis infection in the urban areas, it is plausible that the high incidence is due to the fact that the unskilled labor in the Brazilian construction industry consists primarily of rural migrants (thus former rural workers or small farmers) who were already infected while working at their former profession (Marques et al., 1983).

\section{Deaths according to regions and States}

Considering the absolute frequencies (Table 1) of deaths from paracoccidioidomycosis according to regions, in the Southeast there were 1,707 deaths (53.66\% of the total), as compared to $875(27.51 \%)$ in the South. The two regions together accounted for 2,593 deaths (81.52\%). The Central West reported 318 deaths $(10.00 \%)$, and the North and Northeast together reported $281(8.83 \%)$. The regions with the highest mean number of deaths from paracoccidioidomyco- 


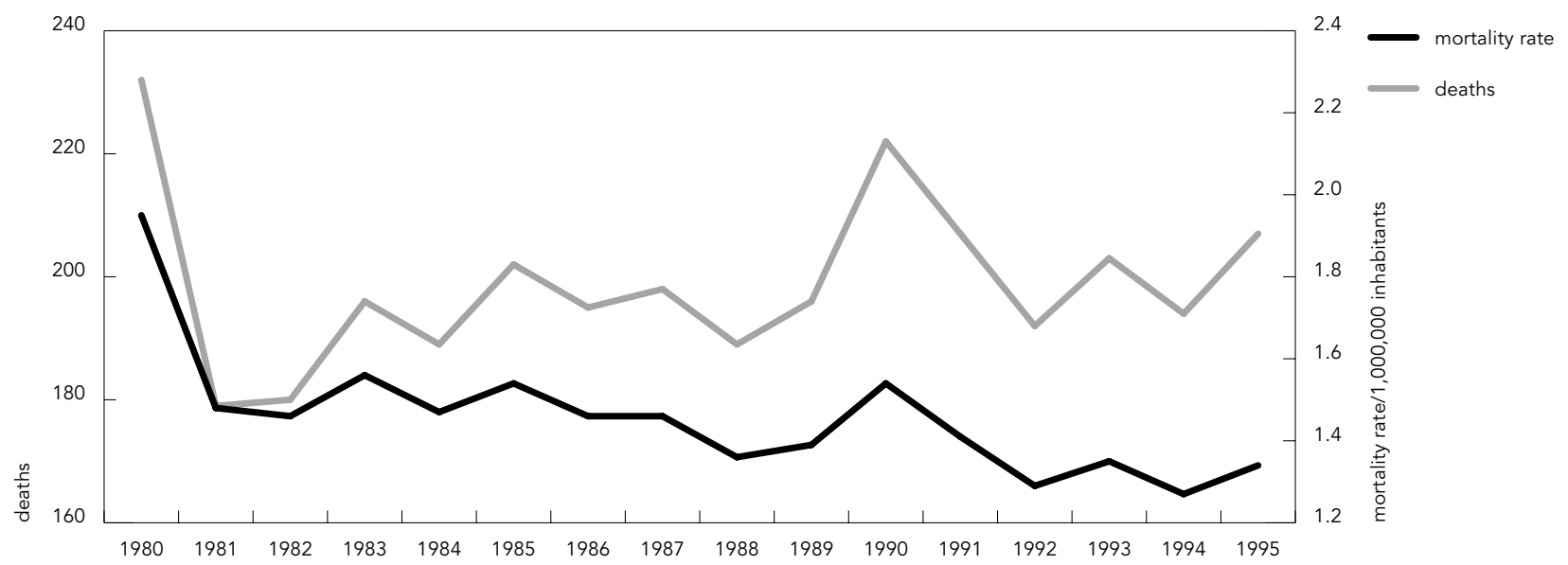

Source: IBGE and DATASUS/MS

Table 2

Proportion of area, overall mortality density, and mortality density from paracoccidioidomycosis and population density by regions. Brazil, 1980 to 1995.

\begin{tabular}{|c|c|c|c|c|c|c|c|}
\hline Region & Deaths (n) & $\begin{array}{l}\text { Total area } \\
\left(\mathrm{km}^{2}\right)[\mathrm{At}]\end{array}$ & $\begin{array}{l}\text { Area of } \\
\text { municipalities } \\
\text { with deaths } \\
\left(\mathrm{km}^{2}\right)[\mathrm{Am}]\end{array}$ & $\begin{array}{l}\text { Proportion } \\
\text { of area } \\
\text { Am/At (\%) }\end{array}$ & $\begin{array}{l}\text { Overall } \\
\text { mortality } \\
\text { density* } \\
\text { (n/At) }\end{array}$ & $\begin{array}{l}\text { Mortality } \\
\text { density }{ }^{\star \star} \\
(\mathrm{n} / \mathrm{Am})\end{array}$ & $\begin{array}{l}\text { Population } \\
\text { density }{ }^{\star \star \star}\end{array}$ \\
\hline North & 151 & $3,869,638$ & 645,982 & 16.69 & 0.39 & 2.34 & 22,964 \\
\hline Northeast & 130 & $1,558,200$ & 81,988 & 5.26 & 0.83 & 15.86 & 255,490 \\
\hline Southeast & 1,707 & 927,286 & 403,517 & 43.52 & 18.41 & 42.30 & 636,473 \\
\hline South & 875 & 564,306 & 235,374 & 41.71 & 15.51 & 37.17 & 374,128 \\
\hline Central West & 318 & $1,612,077$ & 570,235 & 35.37 & 1.97 & 5.58 & 52,525 \\
\hline Brazil & 3,181 & $8,531,508$ & $1,937,097$ & 22.71 & 3.73 & 16.42 & 160,964 \\
\hline
\end{tabular}

Source: DATASUS/MS and IBGE.

* Number of deaths per total area, per $10,000 \mathrm{~km}^{2}$.

$\star *$ Number of deaths per area of municipalities with deaths, per $10,000 \mathrm{~km}^{2}$

$\star \star \star$ Population density by region, per $10,000 \mathrm{~km}^{2}$.

sis were the Southeast, with 106.66 deaths/year, the South, with 54.69, and the Central West, with 19.88.

All States of Brazil reported deaths from paracoccidioidomycosis during the period analyzed, thus characterizing paracoccidioidomycosis as a nationwide endemic, albeit with wide variation among the various States. The five States with the highest absolute frequencies of deaths were São Paulo (29.86\%), Paraná
(14.52\%), Minas Gerais (12.51\%), Rio Grande do Sul $(8.80 \%)$, and Rio de Janeiro $(7.92 \%)$, all located in the South and Southeast.

\section{Deaths by gender and age group}

In the analysis of absolute frequency of deaths from paracoccidioidomycosis according to gen$\mathrm{der}$, there was a predominance of deaths among 
males (84.72\%) (Table 3). The sex ratio was 562 males to 100 females. In the 15 -and-over age bracket, which included $97.15 \%$ of the deaths, the sex ratio was 608 males to 100 females.

Some $3.49 \%$ of paracoccidioidomycosis deaths occurred under 15 years of age (Table 4). These data correlate to the percentages obtained from studies on out-patient and/or inpatient morbidity in areas where the endemic is consolidated. Agricultural frontier areas with intense deforestation can display hyperendemic areas, with the highest percentages of young adults affected (Fonseca et al., 1999; Giménez, 1998; Terra, 1993).

The vast majority of deaths among males (97.14\%) occurred in individuals over 15 years of age, with only $2.37 \%$ among individuals under 15. Among females, most deaths from paracoccidioidomycosis $(89.21 \%)$ also occurred

Table 3

Proportion of paracoccidioidomycosis deaths by gender in five age brackets Brazil, 1980 to 1995.

\begin{tabular}{lrrrrrr}
\hline \multirow{2}{*}{$\begin{array}{l}\text { Age brackets } \\
\text { (years) }\end{array}$} & \multicolumn{2}{c}{ Male } & \multicolumn{2}{c}{ Female } & Unknown & Total \\
& Deaths & $\%$ & Deaths & $\%$ & & Deaths \\
\hline $0-14$ & 64 & 57.66 & 47 & 42.34 & 0 & 111 \\
$15-19$ & 41 & 51.90 & 38 & 48.10 & 0 & 79 \\
$20-29$ & 176 & 74.58 & 60 & 25.42 & 0 & 236 \\
$30-59$ & 1,515 & 88.65 & 193 & 11.29 & 1 & 1,709 \\
60 and over & 886 & 86.35 & 139 & 13.55 & 1 & 1,026 \\
Unknown & 13 & 65.00 & 5 & 25.00 & 2 & 20 \\
Total & $\mathbf{2 , 6 9 5}$ & - & $\mathbf{4 8 2}$ & - & $\mathbf{4}$ & $\mathbf{3 , 1 8 1}$ \\
\hline
\end{tabular}

Source: DATASUS/MS.

Table 4

Proportion of paracoccidioidomycosis deaths by age bracket in males, females, and total. Brazil, 1980 to 1995.

\begin{tabular}{lrrrrrrr}
\hline \multirow{2}{*}{$\begin{array}{l}\text { Age brackets } \\
\text { (years) }\end{array}$} & \multicolumn{2}{c}{ Male } & \multicolumn{2}{c}{ Female } & Unknown & \multicolumn{2}{c}{ Total } \\
& Deaths & $\%$ & Deaths & $\%$ & & Deaths & $\%$ \\
\hline $0-14$ & 64 & 2.37 & 47 & 9.75 & 0 & 111 & 3.49 \\
$15-19$ & 41 & 1.52 & 38 & 7.88 & 0 & 79 & 2.48 \\
$20-29$ & 176 & 6.53 & 60 & 12.45 & 0 & 236 & 7.42 \\
$30-59$ & 1,515 & 56.22 & 193 & 40.04 & 1 & 1,709 & 53.73 \\
60 and over & 886 & 32.88 & 139 & 28.84 & 1 & 1,026 & 32.25 \\
Unknown & 13 & 0.48 & 5 & 1.04 & 2 & 20 & 0.63 \\
Total & $\mathbf{2 , 6 9 5}$ & 100.00 & $\mathbf{4 8 2}$ & 100.00 & $\mathbf{4}$ & $\mathbf{3 , 1 8 1}$ & $\mathbf{1 0 0 . 0 0}$ \\
\hline
\end{tabular}

Source: DATASUS/MS. over 15 years of age, but $9.75 \%$ did occur under 15 years, that is, nearly five times the percentage observed in males (Table 4 ).

Analysis of the mortality profile from paracoccidioidomycosis according to gender and age bracket (Table 3 ) showed similar death totals for both genders in the groups under 20 years of age. In the groups over 20 years of age, the gender trend was inverted. Despite a slight change in the pattern in the 60 -and-over age bracket, males showed upward percentages of total deaths as the age brackets increased. Inversely, females showed downward percentages of total deaths as the age brackets increased.

Analyzing the accumulated frequency between the two genders, there was a higher percentage of females under 30 years of age $(30.08 \%)$. For males, the same age group showed an accumulated frequency of $10.42 \%$ (Table 4 ). This trend was inverted in the two age groups over 30 years of age. This fact may indicate the need for more in-depth studies, since it may be related to difficulty in diagnosing the disease among young girls and adolescent and young adult females.

With regard to central tendency indices, both the mean and median for all deaths were 53 years. The two indices were the same for males (54 years), while for females the mean was 47 and the median 48 years. Mean and median data reiterate that the endemic heavily affects older age brackets, highlighting the ages around which health care and programmatic activities should be intensified. The mode both for all deaths and for males was 57 years. For females there was a bimodal pattern, with peaks at 17 and 62 years. It is important to note that both these peaks occur at ages when women undergo major hormonal transformations.

\section{Mortality rate by region and State}

The States displaying mortality rates or relative frequencies per million inhabitants (Table 1) higher than the Brazilian mean were as follows, in decreasing order: Mato Grosso do Sul (4.39); Rondônia (3.65); Paraná (3.52); Mato Grosso (3.22); Acre (2.96); Espírito Santo (2.79); São Paulo (2.02); Rio Grande do Sul (2.02); Santa Catarina (1.97); Goiás (1.69); and Minas Gerais (1.66). In the North, two States displayed mean annual paracoccidioidomycosis mortality rates above the national mean: Rondônia and Acre. The recently created State of Tocantins showed a rate close to the national mean. All of the States of the Northeast showed rates below the national mean, and none of them had a mor- 
tality rate greater than 1.00 per million inhabitants. Still, the States of Piauí, Bahia, Maranhão, and Alagoas showed coefficients greater than $0.20 /$ million inhabitants.

\section{Mortality rate by gender and age group}

Males showed a paracoccidioidomycosis mortality rate of 2.42 per million inhabitants, approximately five times that of females $(0.43$ per million inhabitants). In all the age brackets studied, males had higher (and progressively increasing) mortality rates (Figure 3 ).

In the age groups under 20 years, the mortality rates were similar for the two sexes, although there was a slight preponderance of males. These data agree with findings by other authors (Negroni, 1993; Wanke \& Londero, 1994, 1998).

From 20 to 30 years of age, the mortality rate was three times as high among males as compared to females. From 30 years upward, the difference increased very significantly. The paracoccidioidomycosis mortality rate in the 30-59-year bracket in males was 7.53 times that of females. These data agree with findings reported in the literature based on morbidity studies (Bethlem et al., 1991; Londero \& Ramos, 1990; Restrepo-Moreno \& Greer, 1983; Valle et al., 1992).

The over-60 bracket showed the highest paracoccidioidomycosis mortality rates for both sexes, but again with a predominance among males. This finding can be attributed to the fact that the cumulative effect of occupational diseases with a drawn-out evolution, like pneumoconioses, occupational neoplasms, and paracoccidioidomycosis, leads to clinical manifestations, sequelae, and death at more advanced ages (Mendes, 1980).

Analysis of mortality from paracoccidioidomycosis by gender also reaffirms the differential percentages in incidence before and after puberty, in agreement with observations by other authors (Andrade, 1983; Bethlem et al., 1991; Hildebrand et al., 1987; Londero \& Ramos, 1990; Restrepo-Moreno \& Greer, 1983; Valle et al., 1992).

The data corroborate research suggesting the possibility of a protective role for the female hormone estrogen, inhibiting myceliumto-yeast transformation of the fungus (Restrepo et al., 1984; Salazar et al., 1988; Severo et al., 1998). Still, other factors may intervene in this predilection for the male gender, like men's greater exposure to sources of infection as determined by the characteristics of their participation in the labor market.

\section{Mortality rates in the regions according to age bracket}

The mortality rates differed considerably when comparing the five major geographic regions of

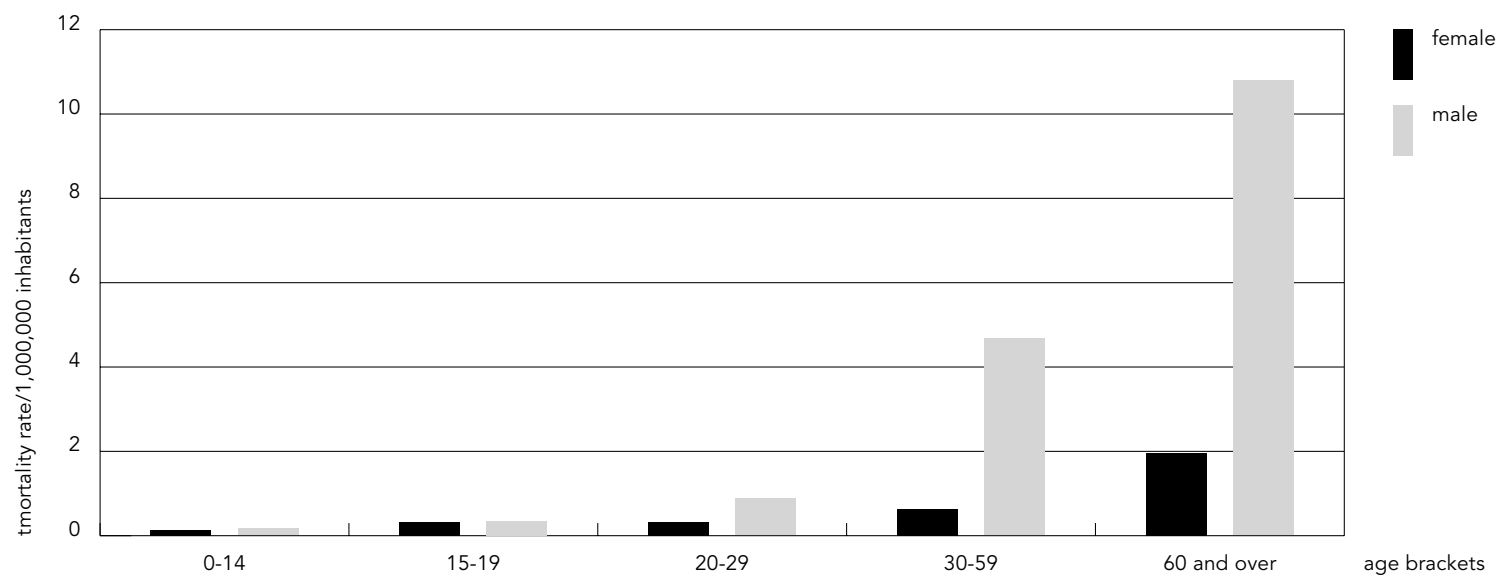

Source: DATASUS/MS and IBGE. 
Brazil according to age brackets (Figure 4). In the South, Central West, and Southeast, a major mortality burden fell on the most productive age group, i.e., from 30 to 59 years of age. These three regions showed mean rates of 5.16, 4.29 , and $2.89 /$ million inhabitants, respectively, as compared to the national mean of 2.68/ million inhabitants. The mortality rates under 30 years of age, with the exception of the 20-29year group in the Central West (with a rate of $1.23 /$ million inhabitants), were homogeneously low for all regions of the country. These findings may be due to the fact that these age groups are less exposed to the etiologic agent.

Although mortality from all causes is naturally higher in the more advanced age brackets, paracoccidioidomycosis mortality was especially high in the over-60 group, with the highest rates in the South $(12.48 /$ million inhabitants), followed closely by the Central West (12.36/million inhabitants) and Southeast (8.04/million inhabitants). These findings appear to contradict morbidity studies by Martins et al. (1986) and Londero \& Ramos (1990, apud Wanke \& Londero, 1998), according to which the frequency of paracoccidioidomycosis decreases gradually after 50 years of age.

The Northeast had the lowest mortality rates of all the regions of Brazil and in all age brackets. This region also displayed the lowest specific mortality rates in the 30-50 and over60 age brackets. These data appear to reflect the low prevalence of this disease in the Northeast. However, it is important to note that in general the Northeast of Brazil has high rates of underreporting of deaths and a high percentage of deaths from poorly defined causes (Reis, 1999).

A portion of the deaths from paracoccidioidomycosis in the more sparsely inhabited regions, principally the North and Central West, may express highly dynamic processes triggered two or three decades previously in socalled "reserváreas" (Borelli, 1964) from other regions of the country (South/Southeast), since this social mobility is characteristic of the macro processes that transformed the Brazilian countryside during those decades. It is possible that in some regions, especially those with fewer deaths, the data represent imported cases related to old and latent infections acquired outside the region where death occurred, since a major portion of the chronic forms in adults results from reactivation of quiescent foci (Wanke, 1998). However, these deaths may also express complex processes originating in local ecotopes of $P$. brasiliensis, thus characterizing them as autochthonous. The accelerated transformations in recent decades in the North and Central West may have contributed to the exposure of susceptible rural workers and/or their families to sources of infection by $P$. brasiliensis (Coimbra Jr. et al., 1994; Fonseca et al., 1999; Veras, 1995).

Figure 4

Paracoccidioidomycosis mortality by region and five age brackets. Brazil, 1980-1995.

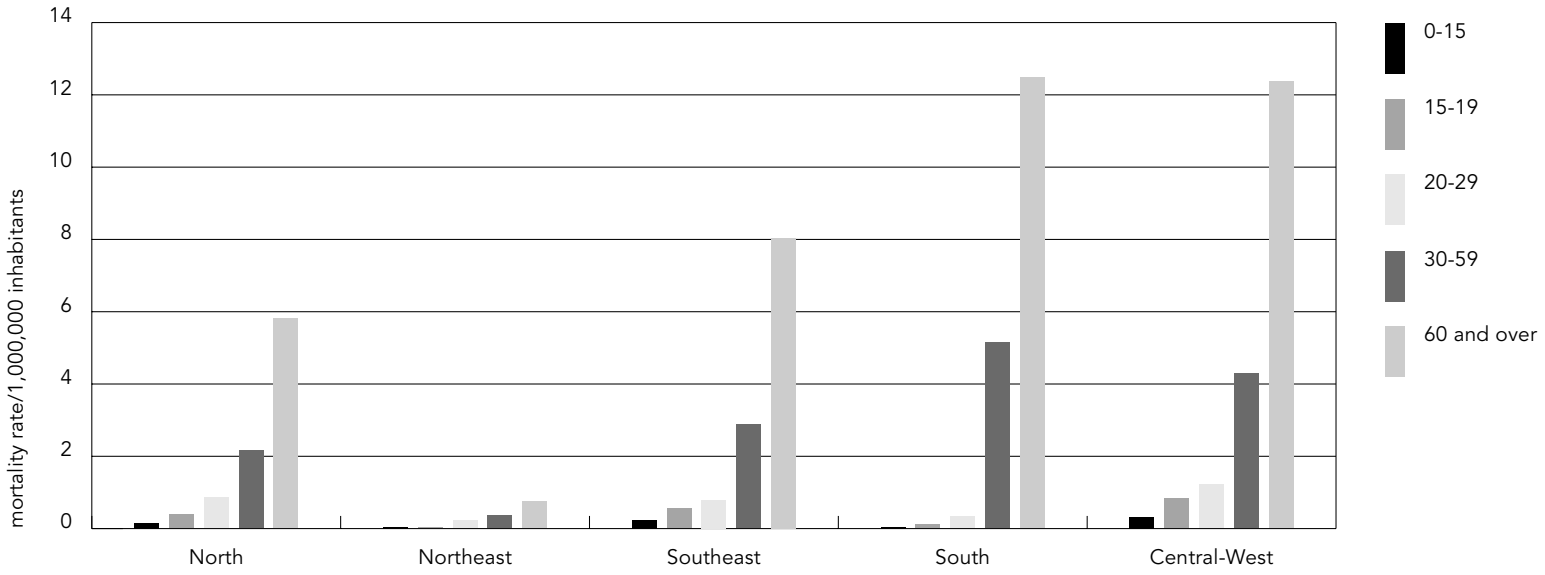

Source: DATASUS/MS and IBGE.

Note: Does not include 19 deaths with age unknown. 


\section{Mortality density and other indicators by region and State}

By region, the highest paracoccidioidomycosis overall mortality density rate per 10 thousand $\mathrm{km}^{2}$ (Table 2) was in the Southeast (18.41), followed by the South (15.51). Lower rates occurred in the Central West (1.97), Northeast (0.83), and North (0.39).

São Paulo, one of the States with the highest mortality rates, displayed a high overall mortality density rate (38.18 deaths/ 10 thousand $\mathrm{km}^{2}$ ). Considering only the municipalities that reported the disease, the density rate was 70.64 deaths per 10 thousand $\mathrm{km}^{2}$.

Considering only the mortality density for the area of the municipalities where the disease was reported, the Southeast and South still had the highest densities. The Southeast showed a mortality density rate of 42.30 and the South 37.17. The Northeast (15.86) also showed a comparatively high mortality density rate (Table 2).

Considering the region-by-region relationship between population density (Table 2) during the study period and the mortality density (both per 10 thousand $\mathrm{km}^{2}$ ), that is, the population mortality density, the highest proportion was in the South, with one death per 20,067 inhabitants $/ 10$ thousand $\mathrm{km}^{2}$. In the Central West there was one death per 26,830 inhabitants/ 10 thousand $\mathrm{km}^{2}$, and in the Southeast there was one death for every 34,485 inhabitants/10 thousand $\mathrm{km}^{2}$. The North and Northeast had the lowest proportions: one death per 58,777 and 308,429 inhabitants/ 10 thousand $\mathrm{km}^{2}$, respectively.

All of the States in the South, Southeast, and Central West (except Rio de Janeiro and the Federal District) showed proportions of total paracoccidioidomycosis deaths that were higher than their respective populations (as a proportion of the total national population). The States of Rondônia and Acre in the North also had proportions of total paracoccidioidomycosis deaths that were higher than their respective shares of the national population during the same period.

Mortality dispersion occurred differently among the municipalities. The Southeast showed a mortality dispersion in 583 municipalities (35\%), the South in 356 (31\%), and the Central West in 106 (24\%). Meanwhile, in the North and Northeast, cases were concentrated in relatively few municipalities, 50 (11\%) and 71 (4\%), respectively, more particularly in the State capitals.

For all States of Brazil, the highest mortality dispersion rates among municipalities occurred in Rio de Janeiro, Espírito Santo, São Paulo, Paraná, and Mato Grosso do Sul. In these States, more than $40 \%$ of the municipalities recorded at least one death from paracoccidioidomycosis.

This dispersion can be explained by the existence of a more highly developed health services network, distributed relatively homogeneously throughout the interior of these States, with greater diagnostic and therapeutic capability.

Analyzing the proportional area (Table 2) affected in the Southeast, deaths from paracoccidioidomycosis were reported in a total area of $403,517 \mathrm{~km}^{2}$ ( $43.52 \%$ of the region's area; in the South the figure was $235,374 \mathrm{~km}^{2}(41.71 \%)$; and in the Central West, $570,235 \mathrm{~km}^{2}$ (35.37\%). The North and Northeast reported deaths in $645,982 \mathrm{~km}^{2}$ (16.69\%) and 81,988 km² (5.26\%) of their respective territories.

Analyzing the State-by-State mortality dispersion by area affected, the States of Rio de Janeiro, São Paulo, Espírito Santo, Paraná, and Mato Grosso do Sul had over 50\% of their respective areas with deaths reported from paracoccidioidomycosis.

Analyzing the mortality dispersion for blastomycotic infections in the greater metropoli$\tan$ areas, of the 3,185 deaths that occurred in Brazil, 585 (18.37\%) were in these areas. These metropolitan areas represented only $3 \%$ of all Brazilian municipalities and some $31.35 \%$ of the country's total population from 1991 to 1995. The greater metropolitan areas with the largest contingents of deaths from blastomycotic infections were São Paulo, with 235 (7.38\%); Rio de Janeiro, with 113 (3.55\%); and Curitiba, with 80 (2.51\%).

The State capitals reported 458 (14.40\%) of all deaths from paracoccidioidomycosis in Brazil. The State capitals in the South and Southeast had a low concentration of deaths from paracoccidioidomycosis, varying from zero in Florianópolis up to 137 (14\%) in São Paulo.

The State capitals of the Northeast had the highest concentration of deaths in capital cities: 48 deaths or $37 \%$ of the regional total. The Central West and North also displayed a high polarity of such deaths in their State capitals, with $106(33 \%)$ and $47(31 \%)$, respectively. Note that Manaus, capital of the State of Amazonas, had $100 \%$ of the paracoccidioidomycosis deaths in that State, while Teresina had $80 \%$ of such deaths in Piauí. This polarization in State capitals is probably due to the concentration of more complex health care services in these cities, capable of diagnosing and treating paracoccidioidomycosis.

In general, the data showed that despite an intense migratory process, especially to the 
State capitals and large metropolitan areas, paracoccidioidomycosis remains as an endemic among the population residing in non-metropolitan, inland, and rural areas.

\section{Temporal distribution of mortality rates and other indicators}

The South of Brazil displayed a paracoccidioidomycosis mortality rate of 2.59 per million inhabitants for the period from 1980 to 1995 (Table 1), or the highest regional rate observed from the data. However, the annual rates showed a sharp downward trend, with an overall reduction of $37.19 \%$ during the period studied (Figure 5).

The South also showed a proportion of total paracoccidioidomycosis deaths that was twice the region's share of the national population. In addition, it displayed less polarization of deaths in the State capitals and high dispersion and overall mortality density.

In the Southeast, the mean annual mortality rate was 1.81 per million inhabitants, that is, higher than the Brazilian national rate. As in the South, there was a downward trend, but the drop was less, that is, $31.22 \%$. The proportion of total paracoccidioidomycosis deaths was greater than the region's share of the national population. There was a low concentration of deaths in the State capitals, showing a greater dispersion, and a high overall mortality density.
The majority of the States in the South and Southeast displayed mortality rates higher than the national rate. The State of Rio de Janeiro was the only one to show a mortality rate below the national average.

These two regions of Brazil have better social facilities networks, including a more capillary health services network, with greater technological capability, both in health care itself and in training human resources. Coverage in these health services is more universal, allowing greater access by low-income segments of the population, as in the case of agricultural workers and urban construction workers.

These regions have also undergone deeper changes in their organizational patterns and are located in areas with a more temperate climate and cooler temperatures, apparently more favorable to the maintenance and reproduction of $P$. brasiliensis in its natural habitat. Still, due to the large area, there is a great diversity of physiographic characteristics (soil, temperature, altitude, rainfall, and terrain).

The Central West showed a mean annual mortality rate of 2.35 per million inhabitants, the second highest rate in the country. However, unlike the South and Southeast, it displayed an upward trend. Deaths were polarized in the State capitals and were moderately dispersed.

The North had a mean mortality rate below the national average, with 1.06 per million inhabitants. As in the Central West, the region showed an upward trend, with an irregular pat-

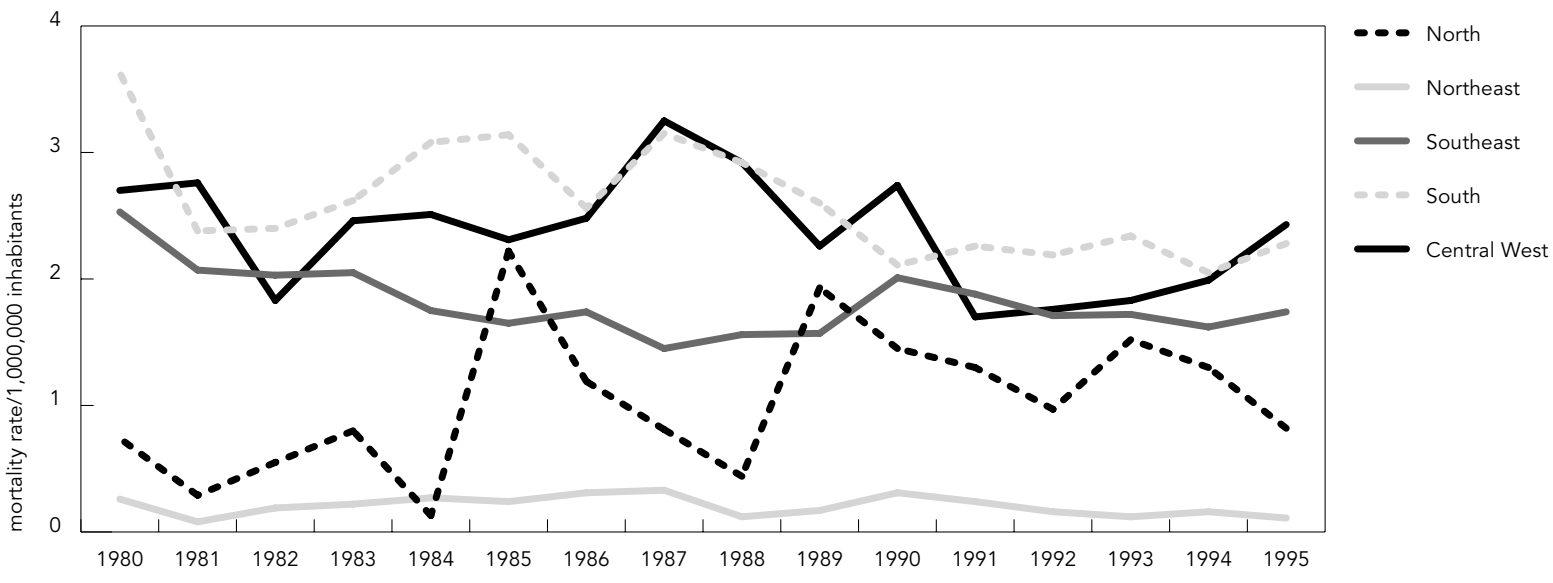

Source: DATASUS/MS and IBGE. 
tern. The proportion of total paracoccidioidomycosis deaths was low. There was a high polarity of deaths in the State capitals. Dispersion was low, as was overall mortality density from paracoccidioidomycosis.

The States of the Central West (except the Federal District) had rates above the national average. In the North, two States had mortality rates above the national average: Rondônia and Acre.

The Central West and North represent new agricultural frontiers and have undergone accelerated transformations in their original environment in recent decades, with intense social mobility, implementation of large-scale agricultural and cattle-raising projects, occupation of new farming areas by small and medium farmers, systematic deforestation of native areas, extensive seasonal slashing and burning, etc. In an initial approach, all these factors could facilitate greater exposure to the ecotopes in which the fungus is found in nature, thereby allowing for human contamination (Fonseca et al., 1999). There is also a major lack of social facilities and technological support in the local health system to perform accurate, early etiologic diagnosis of this mycosis. Access to health care services also tends to be difficult, especially for lower-income and socially less integrated groups. This configuration is doubtless reflected in the irregular trend in paracoccidioidomycosis mortality in these regions.

The Northeast showed a mortality rate of 0.20 per million inhabitants, the lowest of all the regions of the country. The rate also tended to be stable, with the lowest rates observed every year during the period analyzed. The proportion of all deaths from paracoccidioidomycosis was low as compared to the region's high percentage of the national population during the period studied. There was a high polarity of deaths in the State capitals and low overall mortality density.

All of the States in the Northeast had mortality rates below the national average, and none had a death rate greater than 1.00 per million inhabitants.

In the Northeast, the socio-environmental conditions, climate, and lack of forests appear to be adverse to $P$. brasiliensis. It is also possible that conditions in the region are unfavorable for expression of the disease by the human host, since intradermal tests with paracoccidioidin showed high rates of positive reactions for $P$. brasiliensis infection (Fava \& Fava Netto, 1998). Note also that the low paracoccidioidomycosis death rates in the Northeast may re- sult at least partially from the high percentage of deaths classified as having unknown causes in this region (Reis, 1999), in addition to the health services' limited availability and caseresolving capacity.

\section{Final remarks}

Mortality data in Brazil, as in the majority of peripheral countries, suffer from underreporting, high death rates associated with lack of medical care, and deaths from indeterminate causes. Since paracoccidioidomycosis is a disease that mainly affects economically underprivileged population groups working in traditional agriculture, particularly the most underserved segments of the rural population, such implications must be taken into consideration. In addition, paracoccidioidomycosis as the possible cause of death can be obscured by the fact that it is a chronic and disabling disease with a relatively difficult diagnosis that requires laboratory resources with trained personnel to identify the etiologic agent.

The current mortality study has demonstrated that paracoccidioidomycosis is an important health problem whose magnitude is in keeping with that of other major endemics in Brazil. The mortality rate is higher than that of leishmaniasis, and it is the eighth most common cause of death among the chronic/recurrent infectious and parasitic diseases. In addition, it is the systemic mycosis with the highest mortality rate in Brazil. Nevertheless, this endemic has been marked by low visibility and has failed to mobilize resources and attention to prevent disabilities and premature deaths affecting large underprivileged social segments in their fully productive years.

According to this study, paracoccidioidomycosis, as a collective phenomenon, was not distributed homogeneously in Brazilian territory, but expressed distinct spatial distribution patterns. Analysis of the epidemiological characteristics of this systemic mycosis indicates that the endemic presents a set of general determinant processes subordinated to specific socioeconomic macro processes in the various Brazilian regions, the health care structure, migratory flow, and environmental and biological variables related to the fungus and the human host.

Thus, the macro processes involved in Brazil's industrialization and accelerated urban development and which accounted for the concentration of nearly $80 \%$ of the Brazilian population in cities (IBGE, 1997) appear to contribute to the $31.28 \%$ drop in the paracoc- 
cidioidomycosis mortality rate during the period analyzed.

As part of the same development model, the Brazilian countryside also witnessed a relative increase in the number of both salaried farm workers on large farm operations and small-scale family farmers, even in the more developed regions of the country, thus maintaining and renewing (Oliveira, 1995) a stable contingent of individuals susceptible to paracoccidioidomycosis in the rural areas of the country.

The risk of contracting the infection by inhaling $P$. brasiliensis propagules is a reality for this contingent of susceptible individuals from an early age onward, regardless of gender, in the fields and around their rural dwellings and workplaces, around ecological niches, which present the necessary physiographic conditions for maintaining reproduction of this fungus (Fonseca et al., 1999; Gonçalves et al., 1998; Pedrosa, 1976).

Physiographic factors appear to intervene in maintaining the reproduction of paracoccidioidomycosis in the various regions of Brazil. The physiographic factors vary extensively both within and between regions of the country as a function of the dimensions and conditions in the terrain, together with the dynamics of the atmospheric systems. The approach to the relationship between paracoccidioidomycosis and these factors (temperature, rainfall, and altitude) would shed more light on the issue by focusing on smaller spatial units and thus providing more accurate measurements of the real situation.

In the more economically dynamic and heavily populated areas located in the South and Southeast, paracoccidioidomycosis displays high mortality rates that are currently decreasing. These regions appear to present more favorable climatic conditions for development of the etiologic agent (Marques, 1998; Restrepo-Moreno, 1994), although $P$. brasiliensis infection is distributed throughout the country, as demonstrated by the prevalence rates estimated by intradermal sensitivity surveys with paracoccidioidin (Fava \& Fava Netto, 1998). Meanwhile, in the North and Central West one observes the opposite pattern, with increasing mortality rates, pointing to paracoccidioidomycosis as an emerging health problem.

Among the conditioning factors involved in the process of falling ill to paracoccidioidomycosis, one should also consider the increased exposure of males to sources of the infection, possibly due to their greater participation in the rural Brazilian labor market.
As part of this process, migratory movements appear to contribute to the new spatial profile of paracoccidioidomycosis. This relationship appears in the declining mortality rates, despite the high prevailing thresholds in traditional endemic areas in the South/Southeast and the occurrence of cases and deaths in the Central West and North, which are more recent agricultural frontiers that have attracted part of Brazil's human migratory contingent.

Along with the parasite's own characteristics, the poor living and working conditions affecting the target occupational categories for paracoccidioidomycosis also appear to contribute decisively to both the appearance of clinical manifestations of this mycosis after latent periods, resistance to reinfection, or even the disease's severity.

Analysis of the indicators points to paracoccidioidomycosis as a major health problem in Brazil, affecting social segments participating in the labor market during their most productive years, subjecting them to early and extended impairment, disabling and killing them. These consequences could be avoided if the disease were diagnosed and treated in the early stage, based on available technological resources.

The high mortality burden from paracoccidioidomycosis in the most productive age brackets, despite the existence of technological resources for both diagnosis and treatment, also suggests that such resources are not readily, continuously, and effectively available where they are most needed. The adequate provision of these resources to the health care system could help decrease sequelae and deaths, increasing the quality and duration of life for these individuals.

The endemic regions of Brazil, with major dispersion of deaths in their municipalities, large proportions of their areas affected, high mortality density, and high mortality rates, particularly those showing an upward trend, should be the prime targets for official programs and measures, defined in agreement with the scientific community and with the communities themselves that are affected by paracoccidioidomycosis.

It is crucial that health services be redistributed and reoriented and that availability and access to early and effective diagnostic and therapeutic resources be improved in order to adequately deal with the paracoccidioidomycosis problem in Brazil. 


\section{References}

ANDRADE, A. L. S. S., 1983. Paracoccidioidomicose linfático-abdominal. Contribuição ao seu estudo. Revista de Patologia Tropical, 12:165-256.

BAGATIN, E., 1986. Inquérito epidemiológico com a paracoccidioidina na região de Sorocaba, estado de São Paulo. Anais Brasileiros de Dermatologia, 61:5-8.

BARRETO, M. L. \& CARMO, E. H., 1995. Mudanças em padrões de morbimortalidade: Conceitos e métodos. In: Velhos e Novos Males da Saúde no Brasil. A Evolução do País e de suas Doenças (C. A. Monteiro, org.), pp. 17-30, São Paulo: Editora Hucitec/ Núcleo de Pesquisas Epidemiológicas em Nutrição e Saúde, Universidade de São Paulo.

BETHLEM, N. M.; LEMLE, A.; BETHLEM, E. \& WANKE, B., 1991. Paracoccidioidomycosis. Seminars in Respiratory Medicine, 12:81-97.

BORELLI, D., 1964. Concepto de reservárea. La reducida reservárea de la paracoccidioidomicosis. Dermatología Venezolana, 4:71-77.

COIMBRA Jr., C. E. A.; WANKE, B.; SANTOS, R. V.; VALLE, A. C. F. \& COSTA, R. L. B., 1994. Paracoccidioidin and histoplasmin sensitivity in Tupí-Mondé Amerindian populations from Brazilian Amazonia. Annals of Tropical Medicine and Parasitology, 88:197-207.

FAVA, S. C. \& FAVA NETTO, C., 1998. Epidemiologic surveys of histoplasmin and paracoccidioidin sensitivity in Brazil. Revista do Instituto de Medicina Tropical de São Paulo, 40:155-164.

FONSECA, E. R. S.; PARDAL, P. P. O. \& SEVERO, L. C., 1999. Paracoccidioidomicose em crianças em Belém do Pará. Revista Brasileira de Medicina Tropical, 32:31-33.

FORJAZ, M. H. H., 1989. Estudo da Epidemiologia da Paracoccidioidomicose. Rastreamento de Áreas Endêmicas e de Reserváreas, no Brasil, Através do Traçado do Perfil Migratório Residencial-Profissional de Pacientes Diagnosticados em São Paulo. Tese de Doutorado, São Paulo: Escola Paulista de Medicina, Universidade Federal de São Paulo.

IBGE (Fundação Instituto Brasileiro de Geografia e Estatística), 1981. Anuário Estatístico do Brasil1980. Rio de Janeiro: IBGE.

IBGE (Fundação Instituto Brasileiro de Geografia e Estatística), 1992. Anuário Estatístico do Brasil1991. Rio de Janeiro: IBGE.

IBGE (Fundação Instituto Brasileiro de Geografia e Estatística), 1997. Contagem da População de 1996. Rio de Janeiro: IBGE.

GIMENEZ, M. F., 1998. Paracoccidioidomycosis. Actualizaciones Terapéuticas Dermatológicas, 21: 182-192.

GONÇALVES, A. J. R.; LONDERO, A. T.; TERRA, G. M. F; ROZENBAUM, R.; ABREU, T. F. \& NOGUEIRA, S. A., 1998. Paracoccidioidomycosis in children in the state of Rio de Janeiro (Brazil). Geographic distribution and the study of a "reservaria". $R e$ vista do Instituto de Medicina Tropical de São Paulo, 40:11-13.

HILDEBRAND, T. M.; ROSARIO FILHO, N. A.; TELLES FILHO, F. Q.; COSTA, O.; MIYASAKI, N.; MIRA, J. G. S. \& MIYAKI, M., 1987. Paracoccidioidomicose na criança. Aspectos clínicos e laboratoriais em
25 casos. Jornal de Pediatria, 63:92-97.

KAWA, H., 1998. Organização do Espaço e Produção da Leishmaniose Tegumentar Americana no Município do Rio de Janeiro. Dissertação de Mestrado, Rio de Janeiro: Centro Biomédico, Universidade do Estado do Rio de Janeiro.

LACAZ, C. S., 1982. Evolução dos conhecimentos sobre a paracoccidioidomicose. Um pouco de sua história. In: Paracoccidioidomicose - Blastomicose Sul-Americana (C. S. Lacaz, G. D. Del Negro \& A. M. Fiorillo, org.), pp. 1-9, São Paulo: Sarvier/ Edusp.

LONDERO, A. T. \& RAMOS, C. D., 1990. Paracoccidioidomicose. Estudo clínico e micológico de 260 casos observados no interior do estado do Rio Grande do Sul. Jornal de Pneumologia, 16:129-132.

MARQUES, S. A., 1998. Paracoccidioidomicose. Anais Brasileiros de Dermatologia, 73:455-467.

MARQUES, S. A.; DILLON, N. L.; CAMARGO, R. N. P.; HABERMANN, M. C.; LASTÓRIA, J. C.; BARRAVIEIRA, S. R. C. S.; BRETAN, O. \& MARQUES, M. E. A., 1998. Paracoccidioidomicose: Estudo e aspectos clínicos no departamento de dermatologia da Escola de Medicina de Botucatu (São Paulo - Brasil). Anais Brasileiros de Dermatologia, 73: 411-417.

MARQUES, S. A.; FRANCO, M. F; MENDES, R. P.; SILVA, C. A.; BACCILI, C.; CURCELLI, E. D.; FERACIN, A. C. M.; OLIVEIRA, C. S.; TAGLIARINI, J. V. \& DILLON, N. L., 1983. Aspectos epidemiológicos da paracoccidioidomicose na área endêmica de Botucatu (São Paulo - Brasil). Revista do Instituto de Medicina Tropical de São Paulo, 25:87-92.

MENDES, R., 1980. Atuação da medicina do trabalho no diagnóstico dos problemas de saúde ocupacional. In: Medicina do Trabalho e Doenças Profissionais (R. Mendes, org.), pp. 46-76, São Paulo: Sarvier.

MS (Ministério da Saúde), 1996. Sistema de Informações sobre Mortalidade (SIM): Brasil (1979-1995). CD-ROM. Brasília: Centro Nacional de Epidemiologia/Departamento de Informática do SUS.

NEGRONI, R., 1993. Paracoccidioidomycosis (South American blastomycosis, Lutz, mycosis). Journal of Dermatology, 32:847-859.

OLIVEIRA, A. U., 1995. A agricultura brasileira: Desenvolvimento e contradições. In: Geografia e Meio Ambiente no Brasil (B. K. Becker, A. Christofoletti, F. R. Davidovich \& P. P. Geiger, org.), pp. 280-306, São Paulo: Editora Hucitec/Rio de Janeiro: ABRASCO.

OMS (Organização Mundial da Saúde), 1985. Manual da Classificação Estatística Internacional de Doenças, Lesões e Causas de Óbitos - Nona Conferência de Revisão. São Paulo: Centro Brasileiro de Classificação de Doenças em Português.

PAHO (Pan-American Health Organization), 1972. Paracoccidioidomycosis. Proceedings of the First Pan-American Symposium, Scientific Publication 254. Washington, DC: PAHO.

PEDROSA, P. N., 1976. Paracoccidioidomicose: Inquérito Intradérmico em Zona Rural do Estado do Rio de Janeiro. Dissertação de Mestrado, Rio de Janeiro: Universidade Federal do Rio de Janeiro. 
REIS, A. C. G. V., 1999. Qualidade dos Dados sobre Mortalidade: As Causas Mal Definidas na Região Metropolitana do Rio de Janeiro. Dissertação de Mestrado, Rio de Janeiro: Escola Nacional de Saúde Pública, Fundação Oswaldo Cruz.

RESTREPO, A., 1985. The ecology of Paracoccidioides brasiliensis: A puzzle still unsolved. Journal of Medical and Veterinary Mycology, 23:323-334.

RESTREPO, A.; SALAZAR, M. E.; CANO, L. E.; STOVER, E. P.; FELDMAN, D. \& STEVENS, D. A., 1984. Estrogens inhibit mycelium-to-yeast transformation in fungus Paracoccidioides brasiliensis. Implications for resistance of females to paracoccidioidomycosis. Infection and Immunity, 46:346353.

RESTREPO-MORENO, A. \& GREER, D. L., 1983. Paracoccidioidomycosis. In: Occupational Mycoses (A. F. Di-Salvo, org.), pp. 43-64, Philadelphia: Lea \& Febiger.

RESTREPO-MORENO, A., 1994. Ecology of Paracoccidioides brasiliensis. In: Paracoccidioidomycosis (M. Franco, C. S. Lacaz, A. Restrepo-Moreno \& G. del Negro, ed.), pp. 121-130, Boca Raton: CRC Press.

SALAZAR, M. E.; RESTREPO, A. \& STEVENS, D. A., 1988. Inhibitions by estrogens of conidium-toyeast conversion in the fungus Paracoccidioides brasiliensis. Infection and Immunity, 56:711-713.

SEVERO, L. C.; ROESCH, E. W.; OLIVEIRA, E. A.; ROCHA, M. M. \& LODERO, A. T., 1998. Paracoccidioidomycosis in women. Revista Iberoamericana de Micología, 15:88-89.

SILVA-VERGARA, M. L.; MARTINEZ, R.; CHADU, A.; MADEIRA, A. L.; FREITAS-SILVA, G. \& LEITEMAFFEI, C. M., 1998. Isolation of a Paracoccidioides brasiliensis strain from the soil of a coffee plantation in Ibiá, State of Minas Gerais, Brazil. Medical Mycology, 36:37-42.

TERRA, G. M. F., 1993. Contribuição ao Estudo Clínico da Paracoccidioidomicose na Criança. Dissertação de Mestrado, Rio de Janeiro: Universidade Federal do Rio de Janeiro.
VALLE, A. C. F.; WANKE, B.; WANKE, N. C. F; LIMA, N. S. \& PEREZ, M., 1993. Tratamento da paracoccidioidomicose: Estudo retrospectivo de 500 casos. II - Avaliação dos resultados terapêuticos com sulfanilamídicos, anfotericina B, associação sulfametoxazol/trimetoprim, cetoconazol e miconazol. Anais Brasileira de Dermatologia, 68:65-70.

VALLE, A. C. F.; WANKE, B.; WANKE, N. C. F.; PEIXOTO, T. C. \& PEREZ, M., 1992. Tratamento da paracoccidioidomicose: Estudo retrospectivo de 500 casos. I - Análise clínica, laboratorial e epidemiológica. Anais Brasileiros de Dermatologia, 67:251254.

VERAS, K. N., 1995. Paracoccidioidomicose: Estudo Epidemiológico e Clínico de Pacientes Internados no Hospital de Doenças Infecto-contagiosas (HDIC) em Teresina, Piauí. Identificação de Reservárias nos Estados do Pará e Maranhão. Dissertação de Mestrado, Rio de Janeiro: Instituto Oswaldo Cruz, Fundação Oswaldo Cruz.

WANKE, B., 1976. Paracoccidioidomicose: Inquérito Intradérmico em Zona Urbana do Município do Rio de Janeiro. Dissertação de Mestrado, Rio de Janeiro: Universidade Federal do Rio de Janeiro.

WANKE, B., 1998. Desafios em Ciência e Tecnologia no Brasil. Emergência e Reemergência de Doenças Infecciosas e Parasitárias. Programa de Indução Estratégica à Pesquisa em Saúde. Brasília: Conselho Nacional de Desenvolvimento Científico e Tecnológico.

WANKE, B. \& LONDERO, A. T., 1994. Epidemiology and paracoccidioidomycosis infection. In: Paracoccidioidomycosis (M. Franco, C. S. Lacaz, A. Restrepo-Moreno \& G. del Negro, ed.), pp. 109-120, Boca Raton: CRC Press.

WANKE, B. \& LONDERO, A. T., 1998. Paracoccidioides brasiliensis. In: Microbiology and Microbial Infections. Medical Mycology (L. Ajello \& R. J. Hay, ed.), v. 4, pp. 395-407, 9th Ed. London: Arnold.

Submitted on 26 March 2001

Final version resubmitted on 4 April 2002

Approved on 17 May 2002 